\title{
STEPHEN CONGAR AND THE ESTABLISHMENT OF THE NEWARK PUBLIC SCHOOL SYSTEM
}

\author{
BY DONALD RAICHLE
}

\section{Dr. Raichle is professor of history at Kean College in New Jersey}

$\mathrm{F}$

OUNDERS of the American public school included lawyers, clergymen, businessmen, physicians, and even an occasional teacher, but specialists were few. Educational reform was championed by diverse individuals from all classes, each for his own reasons. ${ }^{1}$ The lines between professions were considerably less rigid than those that now separate specialties within a profession. By midnineteenth century, he who had command of the "higher branches," self-taught, learned in the academies, or both, established a fair claim to the title of professor even in the absence of any earned degree. In the west, missionaries played a leading role ${ }^{2}$ in New Jersey, physicians were much more prominent. The early nineteenth-century physician with ample leisure felt little of the pressure of time that now constricts the activities of his successor. Moreover, leisure time then tended to be devoted to community activity rather than to recreation; golf was not yet popular.

The M. D. was much easier then to come by; Marcus Whitman, later a missionary in the Oregon country, became a physician only because he could not afford to educate himself to be a minister. ${ }^{3}$ The attitude toward the profession itself was different; among the upper classes, a young man might take a medical degree simply for the prestige of the title, becoming what a later generation called a "flagrantly non-practicing doctor." Those faced with the necessity of earning a living prized the degree even more. The time expended

${ }^{1}$ Edward Pessen, Most Uncommon Jacksonians: The Radical Leaders of the Early Labor Movement (Albany, N.Y.: State University of New York Press, 1967) pp. 184$187,201$.

${ }^{2}$ David Tyack, "The Kingdom of God and the Common School: Protestant Ministers and the Awakening in the West" 36 (Harvard Educational Review) Fall 1966, pp. $447-469$.

${ }^{3}$ Nard Jones, The Great Command: The Story of Marcus and Narcissa Whitman and the Oregon Country Pioneers (Boston and Toronto: Little, Brown, r959) p. 24.

${ }^{4}$ Nathaniel Burt, Perennial Philadelphians: The Anatomy of an American Aristocracy (Boston: Little, Brown, 1963) p. 101. 
to obtain one was slight and, degree in hand, the physician might or might not practice depending on the opportunities that presented themselves. Whatever he did, it could do no harm to be addressed as "doctor." Even when he did practice, his patients might take up little of his time.

Dr. Samuel H. Pennington of Newark not only had a reputation as a medical scholar but founded and ran the Newark City Bank. Still, he joined other physicians to teach at teachers' institutes and he presided over the Newark Board of Education. ${ }^{5}$ Other physicians, more reformers than promoters, gave even more time to the task of building the public schools of New Jersey. Among the best educated of their day, they were understandably drawn to school work. Where they felt the impulse to reform, they could find no field more demanding of the time and the talents of educated men than the creation of the common school. Administrative posts, such as school superintendencies, were then part-time jobs and physicians could fill them and still continue their practices.

The first State Superintendent of Schools, who served from I 846 to I 852 , was Dr. Theodore F. King, a physician from Perth Amboy. ${ }^{6}$ Another physician, Dr. John H. Phillips, succeeded him and served from 1852 to 1860 . In New Jersey in the I 840 s and 1850 s the common schools had barely begun to emerge. A state teachers convention passed a resolution in 1853 indicating displeasure with the encroachment of another profession on the territory of teachers. The resolution noted that neither of the two New Jersey superintendents had any teaching experience, but Phillips did not feel threatened by the action. As the superintendent was paid only $\$ 500$ annually, ${ }^{7}$ only a person who had other means of support could afford to give his time. Furthermore, no educator of suitable stature was available at the salary offered, so Phillips held the post another

\footnotetext{
${ }^{5}$ New Jersey Historical Society, Proceedings, 3rd series, Vol. III, No. 4, pp. 34-40, Second series, Vol. XIII, No. 4, pp. 228-9; The Biographical Encyclopedia of New Jersey in the Nineteenth Century (Philadelphia: Galaxy Publishing Co., 1877) p. 310, and Frederick W. Ricord, ed., Biographical and Genealogical History of the City of Newark and Essex County, NJ, 2 vols. (New York and Chicago: Lewis Publishing Co., 1896) Vol. I, pp. 242-3; New York Teacher, May 1856, Vol. V, p. 419.

${ }^{6}$ Roscoe L. West, Elementary Education in New Jersey: A History (Princeton, NJ: D. Van Nostrand, 1964$)$ p. 28.

${ }^{7}$ John Bodine Thompson, The Evolution of Education in New Jersey (n. p., 1904). The convention had in mind Isaiah Peckham who two years later became principal of both the Newark High School and the Normal School. In order to get him, the convention proposed the annual salary of the state superintendent be tripled.
} 
seven years. The gifted amateur was not yet ready to yield to the professional.

Dr. C. C. Hoaglund, who served as Superintendent of Hillsboro for a dozen years, was credited by one contemporary with being the guiding spirit of "the whole educational movement [in New Jersey] at the middle of the century." Nowhere did Hoaglund serve more effectively than in establishing teachers' institutes to train teachers before the establishment of normal schools in New Jersey. ${ }^{8}$ At least one physician, Dr. William P. P. Sanford, also served as a teacher in the antebellum Newark schools but so sinister was his reputation as a disciplinarian that there is some question as to whether or not his contribution was positive. ${ }^{9}$ Dr. Charles Skelton, dubbed the "Father of Public Schools," opened a free public school in Nottington in I 844 and became Superintendent of Schools of Trenton in $1848 .^{10}$

Teaching also served as a way station to medical practice as it did to other careers. Sherburne R. Merrill, a New Englander who came to Paterson in $\mathrm{I} 848$, taught as many as two hundred children in one room in that city, using the Lancastrian system of student monitors while he studied medicine under Dr. A. W. Rogers. After a sojourn in Philadelphia to attend medical lectures, he returned to Paterson as Dr. Merrill. In this case, attainment of the degree provided the path away from education. Merrill devoted himself to medical practice; long after the Civil War he was still regarded as one of Paterson's more prominent physicians. ${ }^{11}$

Of all the physician-educators in New Jersey who labored to create and nurture schools, none made a greater contribution than Dr. Stephen Congar, whose contemporaries in Newark called him "the Father of our Public School system." " He was truly the gifted amateur. The Congar family had lived in New Jersey since the seventeenth century, probably having emigrated from New England.

${ }^{8}$ Thompson, Education in New Jersey; David Murray, History of Education in New Jersey (Washington, DC: Government Printing Office, 1899) pp. x 70-I 7 In.

${ }^{*}$ Nequark Sentinel of Freedom, 2 September 1890.

${ }^{10}$ Charles H. Tyson, "New Jersey's Attitude Toward the Kansas-Nebraska Act," unpublished master's essay, Seton Hall University, May 1969, p. 9 ; West, Elementary Education in New Jersey, p. 30.

11. William Nelson, Historical Sketch of Schools in Paterson, New Jersey with Notices of Some Schools in the Vicinity (n. p.: Paterson Board of Education, 1877) pp. 40-42.

12 Newark Daily Advertiser, 26 February I 89 , Newark Daily Mercury, 26 February I 859 ; see also Advertiser, 2 April 1859 and Newark Sunday Call, 14 April 1889 , in which John Whitehead, Congar's fellow School Committee and Board of Education member pays similar tribute. 
Stephen Congar's father was a carpetweaver, prosperous enough to see to the private education of his sons. Born in I 8 IO, Stephen took his M.D. from the College of Physicians and Surgeons in New York in I83 I. His younger brother, Horace Newton Congar, became successively lawyer, editor, diplomat, and insurance executive. The Congars were Whigs given to antislavery and other reforms. Horace edited the Newark Daily Mercury, New Jersey's strongest anti-slavery paper, and in I 848 he deserted the Whig banner to help nominate Martin Van Buren to head the Free-Soil ticket. ${ }^{13}$

If the brothers ever had any political differences, the record does not show it. Whether in supporting Stephen in his several successful bids for political office or writing in retrospect during and after the Civil War, Horace showed only the most fraternal enthusiasm for his brother's candidacies and political principles. The Congar reform style reflects a familiar pattern. Comfortable but not rich, highly committed to education, Presbyterians, the brothers were moderately conservative in politics. The Federalist-Whig penchant for playing down class differences with large dollops of patriotism shows through clearly, particularly in Stephen. His first novel, Herbert Wendall, published when he was twenty-five, is a hymn to the glories of the founding of the republic. His patriotic odes and his Fourth of July speeches repeat the theme. ${ }^{14}$ Along with antislavery and education, the Congars supported temperance, libertarianism, and moderate pro-labor legislation. All of their interest in reform was tinged with nativism and suspicion of the growing German element in Newark.

Upon entering medical practice, Stephen Congar attempted to establish himself in the forefront of his profession. He read papers at meetings of medical societies, served as delegate to state medical conventions, ${ }^{15}$ and from 1836 to $184 \mathrm{I}$ served as secretary of the Essex County Medical Society. Although he served, too, as secretary of the Handel and Hayden Society, he does not appear to have been

${ }^{13}$ The Congar Papers in the New Jersey Historical Society include a Conger genealogy. (Members of the family spelled the name differently.) Obituary of H. N. Congar in Newark Daily Advertiser 25 January 1893.

${ }^{14}$ Herbert Wendall: A Tale of the Revolution (New York: Harper Brothers 1835); Newark Sentinel of Freedom, I 2 July 1836 reprints one of the odes; Frank Pierce Hill and Varnum Lansing Collins, compilers, Books Pamphlets and Newspapers Printed at Newark, N.J. I776-19oo (n. p., privately printed, I 902 ), p. 49.

${ }^{15} \mathrm{~J}$. Henry Clark, The First Fifty Years of the District Medical Society of Essex County (Newark, N.J.: published for the author, 1867) pp. 4I,120; New Jersey Medical Society Transactions, $1807-1858$, pp. $321-324$; William H. Shaw, compiler, History of Essex and Bergen Counties, New Jersey 2 Vols. (Philadelphia: Everts and Peck, 1884 ) Vol. I, p. 65 I. 
particularly interested in music. He was to make his most significant contribution in education. After joining the Newark School Committee in 1838 , he served the city schools for more than twenty years.

His initial interest in schooling seems to have been casual. He approached education as he approached medicine and letters; it was another field to explore. ${ }^{16}$ In $\mathrm{r} 84 \mathrm{I}$, while he was still serving on the School Committee, the Whigs elected him to the New Jersey Assembly. Once in the legislature he assumed leadership of the fight to abolish imprisonment for debt and by the end of a year he had succeeded in ramming an effective bill through stubborn opposition. The folks back home loved him for it and returned him to Trenton for another term, with both Whig and Democratic endorsements. In I 843 he turned back an attempt to repeal his reform measure, becoming something of a local hero. Supporters thronged to meet him at the railroad depot and greeted him with a salute from a cannon. "The Poor Man's Friend," as they dubbed him, returned to Trenton the following year to introduce a bill further strengthening the defense of debtors by making habeas corpus available to them and to take up the cudgels for home rule when it was threatened in New Providence, Rahway, and Caldwell.17

Meanwhile, Congar continued to serve on the Newark School Committee and to study the needs of the schools in his own city and elsewhere. In these early years the schools of New Jersey were, as the trustees of the state school fund overcautiously noted in I 843, "not what they ought to be." Statute law gave the Newark School Committee authority to support common schools or schools for poor children, at the option of the Common Council. ${ }^{19}$ The Common Council had opted for the latter, continuing a policy dating from I 8 I 3 when $\$ 500$ had been raised in Newark for the schooling of poor children in what were called "free schools," "poor schools," or "charity schools." Hope of widening educational opportunity quickened when the state began distributing income from the school fund

\footnotetext{
${ }^{16}$ Index to the Newark Daily Advertiser, 1832; his membership card in the Handel and Haydn Society is in the Congar Papers, New Jersey Historical Society; Newark Sentinel of Freedom 12 July 1836.

${ }_{17}$ New Jersey Session Laws, I842, pp. I30-131, 1844, p. 126 ; Votes and Proceedings New Jersey Assembly, I 843, pp. 365-374 p. 388; New Jersey Assembly Minutes, 1844, p. 5I 2; Newark Daily Mercury, 20 October 185I, I November 1851, 4 November 185 I. 18 Trustees of the School Fund "Annual Report" in New Jersey Senate Journal, I 843 ; p. 36 .

${ }^{19}$ New Jersey Session Laws 1836 , Section 20, p. 195.
} 
in 1829 . Newark schools also benefited by income from small bequests that had been made to the town. Although resources improved, they remained modest. When Congar joined the School Committee in 1838 , Newark owned not a single school building and housed all its pupils in rented quarters. Not until I 843 did it put up the first city-owned schoolhouse.

Nonetheless, in I 838 the School Committee made some significant reforms. Most important, it ended the practice of distributing part of the school fund to private schools. From then on, all expenditures were to be confined to schools under its direct control. The action anticipated the constitutional ban on aid to religious schools enacted in I 844. In New Jersey, more than any other state in the northeast, Protestant sectarians clung to their own religious schools rather than submerge their differences in the common schools. ${ }^{20}$ Horace Mann and others had built the common school by mandating religious instruction, including Bible-reading, hymns, and prayer on a non-denominational basis. This was the tack taken by the Newark schools in 1838 . Outside New Jersey, the new dispensation ran into sectarian opposition until the conservative Protestant sectarians found themselves allied with the Catholics in opposition. This alliance was too much for Protestant bigotry and resistance began to fade. In I 845, the New Jersey Presbyterian Synod attacked the public schools, whose product it feared was a "race of irreligious and infidel youth." The Synod proposed to establish its own parochial schools. While these were being prepared, the Roman Catholics in Newark asked for part of Newark's share of the state school fund for their parochial schools. In Newark, at least, that request settled the matter; from then on the city was officially committed to common schools. ${ }^{21}$

With funds cut off from private schools, the city schools had to take up the slack. The School Committee responded by establishing a free, public school in each of the four city wards ${ }^{22}$ and at the same

${ }^{20}$ Amory D. Mayo, "The American Common Schools in New York, New Jersey, and Pennsylvania," Report of the United States Commissioner of Education (Washington, D.C.: Government Printing Office, $1897-1898$ ) p. 465 .

${ }^{21}$ City Superintendent, Annual Report, 1855, p. 6. Rush Welter, Popular Education and Democratic Thought in America (New York: Columbia University Press, 1962) pp. Y03-109; retrospective article, "Newark Aforetime," appears in Nequark Sunday Call, I4 April 1889 , recounting an early attempt at a division of the school fund; Newark Board of Education, "Minutes," I May 1846.

${ }^{22}$ City Superintendent, Annual Report, 1855, pp. 6-7; West, Elementary Education in New Jersey, p. 30 credits Charles Skelton with establishing the first free school in 
time established a high school for boys on the second floor of the Bank Street School, owned by the well-known teacher, Nathan Hedges. This gave Newark one of the earliest high schools in the country. Hedges himself, a redoubtable disciplinarian, was the principal. Classicist enough to take his charges through Latin, Hedges taught neither Greek nor higher mathematics; early high schools staffed with a single teacher obviously had their limits. "Boys who failed to get their lessons, ... were not infrequently called out before the class and severely punished." ${ }^{23}$ There is little question that whatever Hedges did teach, he taught it thoroughly.

The four ward schools and the high school were designed for white children only. Black children were accommodated in a "colored school," which Newark had run since I 828. These six schools comprised what Congar described in 1855 as "the germ of our present system of Public Schools." The common principal had been implemented and a beginning made in separating children according to their age and ability.

Expenditures began to soar. From I 837 to I 838 , they virtually doubled despite the depression that had begun in 1837 and that by I 838 had sent 4,000 Newarkers scurrying out of the city to seek jobs. Over the years, of course, the Newark population grew rapidly and school needs outstripped facilities. ${ }^{24}$ When John Whitehead joined the School Committee in I 845 he was appalled at conditions. At his first meeting on the Committee in the old stone schoolhouse on Market Street, a tallow candle serving as the only illumination, he heard a motion put to petition the Common Council for funds for a new schoolhouse. Only two years before the city had built its first schoolhouse and now another was proposed! Whitehead asked for a postponement; he wanted to see for himself what the conditions were. His investigation revealed the appalling state of facilities in the predominantly rented quarters of the schools. There was such crowding in one "Female Department" that girls were reciting in the lobby and the open air. In another school, one unhappy teacher tried to manage a class divided between two floors. A third was so crowded that the overflow spilled out of the classroom and down

New Jersey "as we understand the term" in Nottingham in 1844 . Congar claimed the credit for Newark with four schools in addition to the high school six years earlier.

${ }^{23}$ Quoted in Robert S. Bole and Laurence B. Johnson The New Jersery High School: $A$ History (Princeton, N.J.: D. Van Nostrand, I964) p. 2 I.

${ }^{24}$ Jeannette P. Nichols in Irving Stoddard Kull, ed., New Jersey, a History 6 vols., (New York: American Historical Society, I930-1932) Vol. II, p. 591. 
the stairs. Whitehead returned to the School Committee with a proposal to ask not for one schoolhouse but for three, a proposal that was approved and fully implemented. ${ }^{25}$

The ambitious school building program began in the same year that Nathan Hedges resigned his post at the high school to resume operation of his own private school. No attempt was made to replace Hedges and on I April I 845, without giving its reasons, the Committee abandoned the high school and directed the children to return to their respective ward schools. ${ }^{26}$ The "colored school," too, was threatened as a controversy developed over its financial support, but it survived. Two years later, after a delegation from the School Committee, including Congar, met with representatives of the black community, the "colored school" became a free school. ${ }^{27}$

Another feature of the Newark schools in this decade was the development of facilities for the education of apprentices and others whose occupations prevented them from attending school during the day. The School Committee granted "permission" to the teacher in the North Ward to conduct an evening school in the winter of I $847 .^{28}$

The following year Congar assumed the chairmanship of the School Committee, bringing to his post ten years of service on the Committee, a keen awareness of the direction that school systems elsewhere were taking, a highly devloped knack for organization, and a facile ability to draft statute law. ${ }^{29}$ From this point on, he became more and more deeply committed to the public schools. Realizing that the changes he had helped to bring about in 1838 were only a crude beginning, he sought to provide the legal foundations for further reform. At the first meeting of the School Committee in 1849 , Congar laid before it a draft for the revision of the

25 "Newark Aforetime," Newark Sunday Call, I4 April 1889.

${ }^{26}$ Newark Board of Education, "Minutes" I I March I 845 , 30 June I 845,17 July 1845; Manuscript records of graduates, examinations, and school statistics, I839-19 1 3 (14 vols.) Vol. I, in the New Jersey Historical Society.

${ }^{27}$ Newark Board of Education, "Minutes," 25 August 1845, 23 April 1847, 10 May 1847 .

${ }^{28}$ Newark Board of Education, "Minutes," I6 October 1847.

${ }^{29}$ His three years' experience in the Assembly left him something of a local reputation. He was charged by the city to compile The City Charter and Ordinances of the City of Newark, together with miscellaneous arts of the legislature, relating to the city with an appendix (Newark, N.J. printed at the Daily Advertiser Office, 1858), a substantial job of editing. In 1857 Newark paid him $\$ 850$ for his services. This compares with his $\$ 400$ annual salary as superintendent of schools. (The mayor, incidentally, was paid \$50o.) Common Council, "Minutes" 4 September 1857, 2 November I 855 , manuscript in Newark City Hall. 
state law to provide powers to reorganize and develop the Newark public schools. After consultation with both the School Committee and the Common Council, he sent his draft to Trenton for action by the state legislature where the following year it was enacted into statute law as "An Act to establish public schools in the City of Newark." ${ }^{30}$ No longer did the Common Council have an option to provide either schools for the poor or common schools-the die was cast for common schools.

In I 85 I, Congar accepted the Whig nomination for State Senator from Essex County and won the general election handily. In his career as senator he showed far more interest in schooling than he had as assemblyman. Additional legislation was needed to systematize schools in Newark and in 1853 he introduced in the Senate a new bill which, among other things, converted the School Committee into a Board of Education with widely expanded powers, including, for the first time in New Jersey, the power to elect a city superintendent of schools. The new Board at once elected Congar its first President and also the first City Superintendent of Schools. From I 853 to 1854 he held these posts simultaneously, while also serving as state senator from Essex County. While Congar was Superintendent, the post was only part-time. After him, the Board required the incumbent to devote all his time to his school duties. Choosing George B. Sears, assistant principal of the high school, who was experienced as well in teaching in the academies, the Board installed the first of the professional schoolmen. Congar took the old order with him.

As senator he took time to lend a hand in providing more adequate education for the deaf and dumb. At that time, New Jersey sent children with hearing handicaps to the New York Institution for the Deaf and Dumb, under the direction of Dr. Harvey P. Peet. Peet, who had earned his spurs under the tutelage of Thomas Gallaudet, petitioned New Jersey for additional schooling for New Jersey children at his institution. New York provided seven years of education for its deaf children, New Jersey only six, which Peet thought inadequate. To make his point, he brought some of his pupils to meet with New Jersey legislators and demonstrated their progress. Who better than a physician to understand the need for such legislation? Congar received from Peet a letter of appreciation for the resultant

\footnotetext{
${ }^{30}$ Newark Board of Education, "Minutes," 5 January I849, I6 February 1849; New Jersey Session Laws, I8 50, pp. 60-62.
} 
bill which not only supplied the deficient year but, at the option of the Governor of New Jersey, an additional three years for those who might need them. Acknowledging Congar's leadership in getting the bill passed, Peet acclaimed it as putting New Jersey in the forefront of the nation in this special education. ${ }^{31}$

Congar's major concern, though, was the public school bill for Newark. Since that legislation was passed, he wrote in I 855 , "the Board of Education have steadily pursued the object of establishing a system of Public Schools, which shall afford the opportunity of a good Common School education to every child in the community." In his plans for Newark's public education this popular public figure never doubted community support. He continued, "That the vast majority of our citizens sympathize in our efforts and sustain us by their confidence, is evinced by the large and increasing taxation for school purposes to which they cheerfully submit, and by the thousands of children who flock into our Public Schools." ${ }^{32}$ Writing at the end of $\mathrm{I} 855$, a year of unequalled achievement in the history of the Newark's schools, Congar could take considerable pride in his work. $\mathrm{He}$ was the unquestioned leader both of the School Committee in its latter days and of the new Board of Education. As the Newark Daily Advertiser put it, before Stephen Congar, Newark had only charity schools. ${ }^{33}$ The changes begun in I 838 matured in I 855 , the year Congar produced New Jersey's first system of public schools. Congar had written and guided through the legislature ample enabling powers. He also planned the new system, headed the Board which adopted the plan, and administered the plan as City Superintendent.

In I 850 when the first revision of the school law passed the legislature, Newark schools expended slightly more than $\$ 7,000$. By I 855 , the amount had risen to $\$ 44,224.44$. Congar believed that before I 855, the "most important defect in our system of Public Schools ... was their uniformity of grade." Since the closing of the high school in 1845 , there was no division of the schools on the basis of children's age or ability. Congar changed this in I 855 by establishing three grades of schools; primary, grammar, and high school.

Six primary schools provided the base of the system in which children learned spelling, reading, writing, arithmetic, geography,

${ }^{31} \mathrm{New}$ Jersey Senate Journal i853, pp. 47, 194; New Jersey Session Laws I 853 , pp. $31-33$; Peet to Congar 23 February 1853 , Congar Papers.

${ }^{32}$ City Superintendent, Annual Report 1855, p. 7.

${ }^{33}$ Newark Daily Advertiser, 2 April 1859 . 
and grammar. If facilities and teachers were available, the primary schools were to be divided into two departments: primary, for "the young and uninstructed," and intermediate, for the "somewhat advanced." Wherever possible, boys and girls were chastely separated into male and female departments, both of which were taught exclusively by women.

Admission to the seven grammar schools was by examination. These offered, in addition to the subjects begun in the primary schools, vocal music, history, natural philosophy (biology), astronomy, and algebra. All the grammar school male departments had men principals. It should be remembered that in this period a "principal" was a "principal teacher," who spent his time in the classroom rather than in the seclusion of an office. The female departments in the grammar schools were staffed entirely by women. No grading existed within the grammar schools, which admitted children anywhere between the ages of five and eighteen. As soon as primary school facilities in a district permitted, the grammar schools were to admit no child under the age of seven.

The pride of the new system was the high school, on the corner of Washington and Linden Streets. More imposing than any public school building in Newark up to that time, it commanded a dignity that even the remarkable Nathan Hedges had not been able to invest in its predecessor. The male department consisted of principal, vice principal, usher and two women assistants. The female department had a principal and four assistants. For the first time, Newark offered high school education to girls. With a total faculty of ten, the high school contained more talent than any school yet attempted with public funds in the state of New Jersey. Nearly 400 children swarmed to enroll, but these were only a small minority of children of high school age. For more than a generation the high school admitted less than five per cent of the school population. The very few students who attained the heights of this eminence might learn (in addition to the studies prescribed for the grammar schools) chemistry, physiology, geometry "and the higher mathematics," moral philosophy, bookkeeping, Latin, Greek, and French. All this "as the ability and progress of the pupils may warrant, or the Board of Education may prescribe," which is to say that this erudition would be introduced by steps. Students had to be at least ten years of age and were selected by examination from the grammar schools. A later critic decried the high school as an institution that taught 
"little Latin and less Greek" in its early years which, no doubt, were experimental in devising a systematized course of study. As late as I 872 , the high school was still hoping to be ready "next year" to meet college admission standards. ${ }^{34}$ There were no freshmen, sophomores, juniors, and seniors in this high school. There was at first no grading within the school at all; and for the first half-dozen years of its existence, there was no graduating class. ${ }^{35}$

The great merit of the high school was its faculty. Professor Isaiah Peckham assumed the post of principal of the male department. Educated in the academies of upstate New York, Peckham had served as principal in the Irvington public school. Congar and other members of the School Committee had examined him in I 849 and appointed him principal of the Lock Street School. He had also supervised the Newark Industrial Schools, privately operated charitable institutions which fed and clothed poor children and provided them with elementary education. Peckham had made himself one of New Jersey's outstanding educators, editing educational journals, playing a leading role in the development of the teachers institutes, and serving as the first elected vice president of the New Jersey State Teachers Association (later the New Jersey Education Association). He had been the State Teachers Association choice for State Superintendent of Schools two years before and if teachers had their way the state would have paid enough to attract him. After ten years at the head of the Newark High School, Peckham's reputation was national. ${ }^{36}$ Peckham's colleague at the high school, Vice Principal George B. Sears, was of the same caliber, a man so impressive that the Board selected him to succeed Congar when the latter resigned in I 859. Eliza A. Chase, writer of verse and short stories and principal of one of the Newark district schools, was recruited to head the female department of the high school. Miss

${ }^{34}$ Peter J. Leary, Essex County, N.J., Illustrated. A Souvenir (Newark, N.J.: L. J. Hardham, 1897) ; Newark Board of Education, Annwal Report, 1872 p. 42.

${ }^{35}$ The material for the description of the public school system in 1855 is drawn from the City Superintendent, Annual Report 1855 and the Manuscript records of graduates ... Vol. I.

${ }^{36}$ John Bodine Thompson, The Evolution of Education in Nerw Jersey, an address delivered December 28, 1904 at the celebration of the founding of the New Jersey State Teachers Association (n. p., n. d.). Peckham edited the educational department in The New Jersey Life Boat and Literary Standard, The State Educational Journal and later the New Jersey Department of The New York Teacher; William F. Phelps, "Isaiah Peckham, A Memoir," American Journal of Education, 1866, pp. 743-744; the University of Lewisburg (later Bucknell) awarded him an honorary degree in 1856 , see David Murray, History of Education in New Jersey (Washington, D.C., 1899), pp. 170-1 7 In. 
Chase was remembered with affection and respect well into the twentieth century, exhorting the girls around her to outdo the boys in scholarship and cultivating an appreciation of the arts that at least some of her charges never forgot. ${ }^{37}$ There can be little question that the high school, reflecting quality both in its faculty and in physical resources, added a lustre new in the public schools of New Jersey.

Michael B. Katz has shown that in Massachusetts working classes opposed high schools and in Beverly voted the high school out of existence before it was two years old. The childless opposed it; the least affluent felt it would not benefit their children; finally, working class hostility both to industrialism itself and to affluent educational leaders identified with it came to focus on the high school. ${ }^{38} \mathrm{Com}$ pared to Massachusetts, the opposition to the high school in Newark, although dressed in workingman's rhetoric, had little impact. As the Newark high school began its second year, petitioners urged the Common Council to reduce annual school appropriations to a total of twenty dollars. (Newark appropriated $\$ 6 \mathrm{I}, 502$ for that year.) In addition, petitions adverse to the high school set it down as "aristocratic." Job Wade, a chairmaker, who led dissenters, may or may not have been childless. More importantly he may have represented an artisan's antipathy to industrialization-Newark was already one of the largest manufacturing cities in the United States. The thrust of his petition to eliminate virtually all public schooling in the city certainly does not fit the patterns of the workingmen's attitude of the role of the government in education. Whatever he represented, he had few followers. Petitions presented at two successive meetings of the Common Council contained a total of 31 signatures. $^{39}$

Newark supporters of the high school, no less than Beverly, argued that the high school was an instrument of social mobility; it was designed for "upward leveling." Thirty out of 250 boys in the school were the sons of widows and even the poorest child of the city, argued the Newark Daily Advertiser, may qualify. The only aristocracy was of worth, of good behavior, and of earnest, intellectual diligence. As for the question of who should bear the tax burden,

${ }^{37}$ High School Centennial (1938) p. 76. The Chase stories are in the New Jersey Life Boat, October and December I853. Letter from Eliza Chase to "My dear Girls" (of her class in the high school), I9 October I86o, in New Jersey Historical Society.

${ }^{38}$ Michael B. Katz, The Irony of Early School Reform (Cambridge, Massachusetts: Harvard University Press, I 968 ) p. 85.

${ }^{39}$ Newark Common Council, "Minutes," I February 1856, Newark City Superintendent of Schools, Annual Report 1856, p. 6; Newark Daily Advertiser, 6 February 1856. 
the principle was clear. People must pay according to their property as with every other public expense. Newark had already delayed too long its "late awakening" in the matter of public schools; there was no turning back now. Admittedly, the high school benefited only a minority in the sense that only a minority attended, but that was no excuse to break it up. The high school was not an isolated establishment; it was part of a system. The very prospect of high school stimulated effort throughout all of the schools. ${ }^{40}$

The Advertiser followed very closely the line originally put forth in I 838 and reaffirmed in Henry Barnard's American Journal of Education in 1857 . The design of a public high school included the purpose of widening the appeal of the whole common school system. "It would be a mockery of the idea of such a school," wrote the anonymous high school promoter, "if [among other things] it does not meet the wants of the wealthiest and best educated families, or ... the worthy and talented child from a poor family is shut out from its privileges. ..." One of the most basic appeals was to the principle of competition, an idea probably as widely accepted as any other in nineteenth-century America. Competition would improve the performance of children in the lower grades whether or not they reached the high school; it would provide a measure of the relative value of one lower school against another; it would even improve the quality of private schools which would be spurred to greater effort. In short, the high school would produce a more open school system than could otherwise be attained. ${ }^{41}$ Congar himself did not feel that the high school went far enough and he sought private subvention for "some means" of college for the better high school graduates. Across the Hudson River, New York City had already opened its own public college. The Whig physician had no qualms about meritocracy or reasonable competition in education.

One of the advantages of education in schools, as against what Congar called "house" education (his term for a private tutor), was the pride of competition "not too much indulged." For Congar the great value of the high school consisted in "adding stimulus to the industrious and aspiring in all our schools." ${ }^{42}$ Nor was education solely utilitarian. For both men and women, it was "the charm of

${ }^{40}$ Newark Daily Advertiser 6 February 1856, i 5 February 1856.

41 Anonymous, "Public High School," American Journal of Education 3 (1857) $185-189,185$, I 88 .

${ }_{42}$ Newark City Superintendent, Annual Report 1856 p. I6; Stephen Congar to H. N. Congar i 6 November I86I, Congar Papers. 
prosperity and the solace of adversity." ${ }^{* 3}$ No doubt, the system was in part instrumental, in the sense that it was designed to serve the needs of the economy, the government and the society. But the system was also designed to serve the needs of the child who attended it, to save those who in its absence would know only ignorance, left to "vicious temptation of degraded associations," and even be "tendered the drunkard's cup in infancy." "The Congar system swept the whole field of class, reached out to apprentice as well as to vagrant, and offered the stimulation of aspiration to the "higher branches." The opposition was minimal; the elected Board of Education continued to be reelected. Even in the blight of the depression that began in 1857 and with a measure of felt hostility from the Common Council, the Board of Education kept its schools open and its system intact. ${ }^{45}$ Newark liked Congar's system, priding itself on its schools long after it had forgotten who Stephen Congar was.

With the primary and grammar schools, the high school made up the initial effort at grading, with the added fillip of the intermediate department in the primary schools "where possible." To implement this rudimentary grading, the Board of Education opened a total of fourteen new schools in 1855 . In addition to the high school and seven new grammar schools, the Board established a city public normal school for the training of teachers. This was the first public normal school in New Jersey and, according to one authority, the fifth city normal school in the country. ${ }^{46}$ Indeed it says much about the ability of Newark schools to attract competent teachers at midcentury that Congar thought "grading" rather than the need for better teaching to be the primary deficiency of Newark. Throughout the country, the need for the training of teachers had long been critical. In New Jersey it had occupied the attention of educators far more than the grading of the schools. The establishment of a state normal school had been sought at least since I828. In 1855 the effort at last bore fruit, but when the New Jersey State Normal

${ }^{43}$ Stephen Congar to H. N. Congar, 16 November 1861, Congar Papers.

${ }^{44}$ Newark Daily Advertiser 15 February 1856; Newark Daily Mercury 28 October I $85 \mathrm{I}$.

${ }_{45}$ Newark Board of Education, "Minutes," I9 March 1858, 6 September 1858, I7 September 1858, 20 September 1858, 24 September 1858, 19 August 1859; Nequark Daily Advertiser 25 September $185^{8}$. Congar charged the Common Council was hostile (Newark Daily Advertiser 17 September 1858) to the school system but this might have been only a device to pressure it to grant adequate operating funds in a year when depression had made them scarce.

${ }^{16}$ Frank A. Manny, City Training Schools for Teachers (Washington, D.C.: Government Printing Office, I915), p. 15. 
School opened in Trenton in October of that year it was not the first public normal school in the state. Newark Normal had opened the preceding April. It was a part-time operation (unlike the full-time state institution), holding Saturday morning classes under the tutelage of Peckham, Sears, and Chase of the high school faculty. Parttime perhaps, but it was the most thoroughly graded school in the system, containing five classes, later reduced to four. It offered primary teachers certification after two years, grammar school after three, and a principal's certificate on completion of the entire fouryear course. Congar's "system" was not only graded but structured to provide itself with a steady supply of trained teachers.

A private charitable organization, the Children's Aid Society, had been operating two industrial schools for destitute and vagrant children. These institutions provided day care, food, and clothing as well as offering primary and vocational education. At the behest of Mayor Horace J. Poinier, the Board of Education accepted the responsibility for the educational functions of these schools, leaving the Children's Aid Society the role of providing food and clothing. ${ }^{47}$

In one sense it can be argued that social stratification in midcentury Newark segregated the vagrant and destitute child and visited on him a stigma similar to that placed on the black child in his segregated school. Although true, this criticism misses the main point. As Congar pointed out, the decision to include the industrial schools in the Newark public system struck at earlier segregation of private and charitable schools and brought poor children into the common sytsem. So he staked his claim that Newark thereby "has been foremost among the cities of the United States" in this experiment to educate a class of children "who rarely present themselves voluntarily for admission to the public schools. ${ }^{\text {" }}$ (8 Congar and his Board performed the same services in two Newark schools that Clara Barton offered at about the same time in one school in Bordentown. ${ }^{49}$

The Board also reached out to extend educational opportunities to the less privileged in another way. Apprentices had long played a significant role in the life of Newark. A condition of indenture extending back to the colonial period, commonly stipulated that the master send the apprentice to evening school for a quarter of each

\footnotetext{
${ }^{47}$ Newark Board of Education, "Minutes," 6 March I 855, 25 April I 855.

${ }^{48}$ Newark City Superintendent, Annual Report i 856, p. I r.

${ }^{49}$ West, Elementary Education in New Jersey, pp. 32-33.
} 
year. ${ }^{50}$ Others, too, found a need for evening schools and although such institutions in Newark had existed since the eighteenth century, need had outgrown facilities. ${ }^{51}$ One teacher was granted "permission" to conduct an evening class in his district school. ${ }^{52}$ In $185 \mathrm{I}$, probably at Congar's suggestion, the Newark Daily Mercury began a series of editorials advocating the establishment of free evening schools for apprentices and others. Such schools, declared the Mercury, would prevent the development of "wild and reckless conduct" and improve morality by cultivating industry, punctuality, and self-denial. In good Federalist-Whig rhetoric the Mercury later added that education prevented the development of a class system. ${ }^{53}$ In the revamping of the Newark public schools in 1855 , the Board opened four free evening schools, one for girls and three for boys, offering courses at the grammar school level. The children who sought education in the evening carried no light burden. Schools were open five evenings a week from 7:30 P.M. to 9:00 P.M. Those who have taught mature students at the college level in the evening after both teacher and student have already completed a full day of work can well imagine the difficulties inherent in such a program.

The rigor that characterized the evening schools ran through the whole system. In effect, the Newark public schools were "all year round schools," for the Board calendar prescribed a trimester program that allowed August as the only vacation month and recognized New Year's Day, Christmas, Thanksgiving, and the Fourth of July as the only four holidays. Schools opened at nine o'clock in the morning and closed at four or four-thirty in the afternoon, depending on the time of year. ${ }^{54}$ From 75 to 80 pupils faced the teacher on an average day and classes sometimes ran as high as roo. Corporal punishment was routine. It is difficult to know whether teacher or child carried the heavier burden. It is not necessary to argue that beatings hurt the teacher more than the child to note that the teacher paid heavily in psychic cost in an atmosphere made tense by the rod

${ }^{50}$ Bernard Bailyn, Education in the Formation of American Society: Needs and $O_{p}$ portunities for Study (New York: W. W. Norton, 1960) pp. 29-33.

${ }^{51}$ Joseph Fulford Folsom, et al., eds., The Municipalities of Essex County, New Jersey, r666-1924, 5 vols., (New York: Lewis Historical Publishing, 1925) Vol. I, p. 182 .

52 Newark Board of Education, "Minutes," I 6 October 1847.

${ }^{53}$ Newark Daily Mercury, 17 October 1851 , 12 November 1851 .

${ }^{54}$ Newark Board of Education, "Minutes," 27 June 1849,26 January 1855 . Regulations of the Board of Education. 
or the threat of it. Teachers who spent their Saturday mornings in the normal school, reported Congar's successor, are sometimes "impaired in physical strength; some have barely struggled through and are recuperating under the diminished labor of daily duties, while some I fear will never recover that healthful tone and elasticity of spirit indispensable to success in teaching." The same strain affected students in the high school, particularly in the final year, which was "one of labor and anxiety which seem to have exhausted their vital energies." In part this was characteristic of the nineteenth century, but part was peculiar to Newark. In scarcely any other city did teachers put in as many hours as did those of Newark. ${ }^{55}$

The establishment of the school system did not come then without cost, but still the achievement of I 855 was extraordinary. Newark took a long step forward toward the vaunted goal of "the means of instruction for all of the children of the community, whatever may be their position or circumstances." Well-structured and with strikingly increased resources, Congar's system showed balance. Although it reflected the old Jeffersonian Republican ideal of encouraging and rewarding merit, it also reflected Congar's genuine concern for the underprivileged. His fight for the abolition of imprisonment for debt had been a fight for the workingman. When there had been no schools for apprentices, Congar opened a library for them. When his fellow Whig, Mayor Poinier, spoke up for the industrial schools, Congar and the Board listened and acted (unless, more likely, it was Congar who arranged for the Mayor to use his influence in the first place). Given the close family and political ties of the two brothers, the championship of the evening schools for apprentices by Horace Congar's Mercury is inconceivable except by Stephen's consent, or again more likely, on his initiative. In sum, Congar had reached out to both the affluent and to the poor in constructing a common school system that had special appeal to both groups.

Not that the system offered equal opportunity. In fact, that ideal, imperfectly realized at best, was clearly sought for whites only. Mid-nineteenth century New Jersey, still not free from the last vestige of slavery, had no stomach for putting the black man on a level with the white. The black community was offered only the rudiments of education-and that under an official policy of strictly enforced segregation. No one pretended that the separate "colored

\footnotetext{
55 Newark Board of Education, Annual Report, 1862, p. 25, 1871, pp. $23,56$.
} 
school" was equal to white schools; it was not intended to be. If, as Congar argued, the chief defect in the school system was grading, then the "colored school" went right on being defective. Newark, interestingly enough, did not find it necessary to establish male and female departments in the "colored school." Presumably the Board was not haunted by fears about misconduct between the sexes where blacks were concerned.

In I 859 a black man who wanted a better education for his children than anything the "colored school" could realize, brought his two daughters to apply for admission to the high school. They were, Congar reported, "peaceably advised to withdraw." As he explained to the Board, admission to the high school was open only to qualified graduates of the Newark grammar schools. Since the "colored school" was not a grammar school, there could be no question of admission. In I 855 , Congar had classified the "colored school" as a grammar school ${ }^{56}$ but evidently it ceased to be so in his mind when blacks sought to use it as the means to break the white monopoly of the high school. In Congar's words, exclusion of the blacks was "the plain, common-sense rule." The fact of the matter, as he saw it, was that if black children came into the high school, then white children would leave it; it was that simple. But there were those who saw it differently. One member of the Board of Education pressed the case of blacks hard, no doubt for partisan political reasons, but he faced implacable opposition. Stephen Congar, the conscience Whig whose brother edited the most powerful anti-slavery newspaper in New Jersey, led that opposition. Although Congar explained to the Board that segregation in schools was expensive and that its elimination would be an economy measure, such a move was neither contemplated nor desirable. "There has always been the kindest attention paid to the colored child," taken at face value. Congar had no wish to be unkind nor did he believe he was being so. The history of anti-slavery in America since its beginnings only occasionally ventured the heresy that the black was the equal of the white. ${ }^{58}$ It therefore made no sense to treat him

\footnotetext{
${ }^{56}$ See page of enrollment statistics for term ending in July I 855, manuscript record book of statistics, Vol. I, kept in Stephen Congar's hand.

${ }^{57}$ Newark Board of Education, "Minutes" 25 February 1859; Newark Daily Advertiser, 26 February 1859 ; Newark Evening Journal, 26 February 1859 .

${ }^{58}$ For an early argument for equality, however, see Samuel Sewall, The Selling of Joseph (Boston: University of Massachusetts Press, 1969), a reprint of the 1785 edition, pp. $4 \mathrm{I}^{-42}$.
} 
as an equal. The trick in building the common school was to get most children into it and most Newark children were white. Admission of the black could only thwart that purpose. About a decade earlier, the Supreme Court of Massachusetts had held that "separate but equal" schools were constitutional. The New Jersey constitution differed from that of Massachusetts in that the New Jersey document had no clause stating that all men were created equal. The New Jersey philosophy (without meaning to be unkind) held that the black was not equal and whatever he was entitled to would be decided in the counsels of the white men. The considered judgment of these counsels, the black could not hope to equal; at least, so thought the white men.

There can be no doubt of the stigma attached to the child of the industrial school or of the stubbornness with which such a stigma would cling after school days were over. On the other hand, the advantage over the child in the colored school is patent. While it was not routine, some children from the industrial schools graduated into the grammar schools. From there it was more than theoretically possible to go on to high school. ${ }^{59}$

Congar's school system was also strongly nativist; reflecting an element of his brand of Whig politics and indicating the consensus he shared with the majority on the Board. The election of an Irish Catholic school board member in 1860 brought the charge that the school board had never employed a Catholic teacher. By this time, Congar no longer served the Board, having resigned the year before; but the reaction is revealing. The comment infuriated Dr. Samuel H. Pennington, then President of the Board. White with anger, he surrendered the chair to take the floor for a reply and inform the critic that there was no sectarianism on this Board. Indeed Pennington himself had voted "for teachers whose religion was more obnoxious to him than even the Catholic was" for, "however much the religion may be encumbered with superstitious forms and exactions, it still has a saving element in it." But with all this stirring defense of Catholicism (one dares not speculate about what religion Pennington really objected to), no one contradicted the Catholic's charge. ${ }^{80}$ To have employed a Catholic teacher would have been to

\footnotetext{
${ }^{59}$ Bole and Johnson, New Jersey High School, p. 2 I cites New Jersey Trustees of School Fund Report i 839 that out of 91 boys in Hedges high school In were orphans, which compares with the later high school.

${ }^{80}$ Nequark Evening Journal, 25 February 1860; Newark Daily Advertiser, 25 February 1860 .
} 
abandon the Protestant nondenominationalism on which the schools were based. Yet to recall these shocking elements serves to remind us that the public schools then as now reflected the general climate of the community they served. Only in the twentieth century did Protestant domination of school board and teaching positions pass away.

Another serious deficiency lay in the scope of the Congar achievement. No one knew better than Congar that the system he devised fell far short of the goal of "opportunity of a good Common School education for every child in the community." Justifiably, Congar put the best face on things. He correctly noted that by the end of I 857 , nearly two-thirds of all the children in Newark had attended the public schools for at least a part of the school year. His figures are based on the number of children who registered in the schools. Much more pertinent, if one wishes to know how many children the Newark schools were systematically educating, is the average daily attendance. Only 3,563 children were in average daily attendance compared to a school-age population (five to eighteen years) of I 4,72I. Even if the 400 or so attending the evening schools are added, barely a quarter of the city's children sat at the school desks on an average day. ${ }^{61}$ Of course, some children attended private schools both in and out of Newark. The rate of attendance declined sharply in the upper grades; the higher the grade the lower the attendance. For a full generation only one child in twenty even enrolled in the high school. Still, the difference between the number of pupils who registered in the public schools-10,173 as compared with about 4,000 in average daily attendance in day and evening schools is striking. Worse, in some primary schools, children were actually turned away. ${ }^{62}$ No doubt, these included many who, because of family income or substandard parental care or both, needed schooling most. The Newark experience was not substandard; throughout the country, children stayed away from schools in droves. Not until well into the twentieth century did schools approach the universal in attendance. That more wanted to come than the schools could house, indicates the large base of popular support the schools had. Despite its shortcomings, the system offered to the children of

${ }^{61}$ City Superintendent, Annual Report 1856 , p. 5.

62 These figures are subject to some modification for various reasons. Some children for instance, seemed to have registered in more than one school. But, admittedly, Newark did not provide places for all the children of Newark who wished to attend school, Newark Board of Education, Annual Report 1857, p. 16 and 1859 pp. 30-31. 
Newark a better chance of getting into school than any other in New Jersey. Finally, once in, the child had a fairer chance of education than anywhere else in the state.

As Nelson Burr remarked, Newark set a swift pace for the rest of New Jersey. ${ }^{63}$ A graded school system, topped by a high school which won national recognition, a normal school which turned out a supply of trained teachers that made the Newark school system outstanding for the next century, and the evening and primary industrial schools which gave the school system meaning to the underprivileged-all of this marked an achievement that brought Newark directly into the ranks of the better school systems in the country. The system was for the most part based on a careful study of what the better school systems were already doing, but Congar did claim Newark was "foremost" in developing a system that included the underprivileged.

Contemporaries-John Whitehead, for example, who served both on the old School Committee and new Board, and Dr. Samuel Pennington, who succeeded Congar as Board president-gave Congar the credit for the achievement. Pennington saw him as the "Father of the School System of this city." Thirty years later Whitehead reminded the citizens of Newark that "the present systematized condition of the schools is due almost entirely to his exertions." ${ }^{\prime 4}$ No one ever challenged those views. Planning the design, drafting the legislation, jockeying the legislation through the state legislature, and finally, implementing the system, Congar was the unrivalled leader. As nearly as projects of this kind can be, the establishment of the Newark school system was the work of one man.

That one man, Stephen Congar, had devoted himself so much to his profession and his community that he had done little to make for himself a private life. Until he resigned as City Superintendent and member of the Board of Education in 1859 , he had remained a bachelor. When his younger brother married, the bride was brought under the Congar roof and Stephen stayed on, the respected and beloved elder brother. Then, in 1859, he married Elizabeth Hedden, the widow of a substantial Newark merchant. He took

\footnotetext{
${ }^{63}$ Nelson R. Burr, Education in New Jersey, 1630-1871 (Princeton: Princeton University Press, 1942) p. 289.

${ }^{64}$ Newark Daily Advertiser, 26 February 1859; "Newark Aforetimes," Newark Sunday Call, 7 April 1889.
} 
her to Michigan where she owned a farm that they thought of selling. Not able to sell at what they thought a fair price, they settled down and Stephen Congar turned farmer. His public career ended abruptly, and although he lived until I 897, nearly forty years after his resignation as City Superintendent, apparently he never again played any other public role in either his native New Jersey or his adopted state of Michigan. His letters indicate that he neither continued to practice medicine nor to write novels. He quietly bowed out of all public life.

Not long ago, historians routinely saluted the accomplishments of reformers with respect and admiration. ${ }^{65}$ More recently, these same reformers have fallen on evil days as historians re-examine their careers. Psychology on the one hand, and analysis of class conflict on the other, have contributed to reduce them to less then heroic size. Where abolitionists are seen as paranoid and progressives as frustrated conservatives, ${ }^{68}$ how could the pioneers of public school systems hope to retain their old lustre? The blow came in the I960's. From the pages of a new breed of historian the schoolmen emerged as racist (which they were, although probably less so than most of those around them); manipulators, if not exploiters, of children, working to fit them into a cheerless world of corporate efficiency (which assumes a contradiction between personal fulfillment and a commercially competitive society that the nineteenth-century schoolmen were not apt to admit); "brutal and vindictive" (though not necessarily in their school programs); "totalitarian" in their concept of moral education; and finally, presumptuous enough to shape their objectives in terms of their own perception of social need. ${ }^{\mathrm{ar}}$ And whose perception should or could shape social objectives if not

\footnotetext{
${ }^{85}$ Alice Felt Tyler, Freedom's Ferment: Phases of American Social History to 1860 (Minneapolis: University of Minnesota Press, 1944).

${ }^{86}$ The analysis of reformers has produced a literature of heroic proportions, as heroic as the earlier stature of reformers themselves. There is no attempt here to deal with it in any detail but note, for example, David Donald, Lincoln Reconsidered: Essays on the Civil Era (New York, Vintage, 1956), who analyzes the paranoid tendencies of abolitionists in the essay, "Toward a Reconsideration of Abolitionists," pp. 19-36 and Richard Hofstadter, The Age of Reform: From Bryan to F.D.R. (New York, Vintage, 1960) pp. 143-166 on progressives.

${ }^{67}$ Michael B. Katz, The Irony of Early School Reform (Cambridge, Massachusetts: Harvard University Press, r968), pp. 153, 130-131. For similar views see Michael B. Katz, Class, Bureaucracy and Schools: The Illusion of Educational Change in America, New York, Praeger, 197I, Colin Greer, The Great School Legend: A Revisionist Interpretation of American Public Education (New York, Basic, I972), Joel Spring, Education and the Rise of the Corporate State (Cambridge, Mass., Boston, Beacon Press, 1973).
} 
their own? Even genius does not have the option of reaching outside its own historical circumstances.

Stephen Congar, an active participant in the life of his city and state, knew and dealt with political opposition and with class, race and religious conflicts. $\mathrm{He}$ was well aware that he had not silenced many of the honest voices raised against him and his policies. But he would not have understood some of the more recent charges laid against reformers in general and against schoolmen in particular.

The Fourth of July orator and the writer of patriotic odes and novels shared the belief of the nineteenth century that an immutable moral law undergirded not only the United States government but the whole universe. The Bible he held to be "the Divine source of religious truth and Christian morality-the only sure defences of Liberty and Justice!" The common schools were established to teach "this pure and perfect code of ethics" to children who no longer were being properly inculcated in either religion or morality at home. ${ }^{68}$ Of course, as the revisionist historian charges, this was imposed morality; but even the revisionist recognizes that cultural relativism was then unknown and reformers should not be criticized because they did not accept it. ${ }^{69}$ Why, then, the charges? One must ask, too, if Stephen Congar would not have been remiss by his own lights if he had not "imposed" his morality. Another way to say this is that one generation devised means to pass on its heritage to the next. How can any generation be faulted for this? The real fault would be in failure to make the attempt. It must be said, too, that the revisionist conclusion that there was little of humanitarianism in educational reform does not square with the Newark experience.

In the first place, although the moral law was immutable and eternal, man's acceptance and deference to it was rather less perfect. In I $860 \mathrm{Dr}$. Samuel H. Pennington summed up the underlying fear of "the deterioration of public morals" that had caused such "anxious forebodings in the minds of the wise and good among ourselves." These included the

breaches of public and private faith, the desecration of the Sabbath, the fraud, the violence and the detraction attending our contests for political ascendancy, the corruption and brutality witnessed in our halls of legislation, the prevalence of open, undisguised profligacy and vice among persons occupying prominent positions in public life, and the bloody arbitrament by

${ }^{68}$ Newark City Superintendent, Annual Report, 1856, p. 20.

${ }^{68} \mathrm{Katz}$, Irony, p. I 3 I. 
which personal wrongs are self-vindicated-not to speak of the sectional animosities that exist; and the recklessness of consequences by which abstractionists and demagogues seek to inflame them. . . ${ }^{70}$

Pennington thought the family "very inefficient" as an educational force in developing morality, the pulpit as failing to reach "multitudes," and newspapers inadequate. "To the teacher who, more than any other class, comes into the popular mind in the most impressible period of its development, must the country look for that corrective agency, which is most effectually to arrest the fearful evils impending over us." It was the teacher, then, who was responsible for the inculcation of "faith in God, a sacred regard for the requirements of duty, reverence for station and for age, submission to authority, profound respect for law and the rights and feelings of his fellow-men." On the eve of the Civil War, more than twenty years after the presidency of Andrew Jackson, Pennington could still call for "respect for station" and hold its development as a primary function of the public school. The whole public school movement was a conservative one, to shore up the nation, the economy, the government, the society itself. It is interesting, too, that Pennington the banker played down the role of the school in providing the skills for an industrializing society. His Protestant passion spent itself on exhortations about God, order, and character. Nor, from the point of view of the conservative, was this exploitative, because he believed that harmony invested the social order. Men were not exploited in it; they fulfilled themselves in it. Pennington knew that the justification for education lay in what it did for the individual. The school was charged with the care of children to "develop alike their spiritual and individual natures," to pass on "that knowledge, by which alone the mind can be expanded to the full measure of its capacities, and the soul fitted for everlasting communion with her God." "11

This was the function of the school system that Congar established in Newark, and the unamimous Board resolution that caused Pennington's remarks to be published in the Anmual Report indicated board consensus for the view. It was nineteenth century reform and reeked of some of the worst elements of the nineteenth centuryreactionary conservatism, racism, nativism, and bigotry. Yet it surely

${ }^{70}$ Pennington, "Address," 27 January 1860, in Newark Board of Education, Annual Report 1859 , pp. 27-40, 34 .

71 Pennington, "Address," pp. 34-35, 40. 
was not without humanitarianism. Led by a man whose political career had embraced working class reform, it did not forget the children of the poor. Schoolmen of the 1970's who see the children of the middle classes increasingly withdraw from the public schools to enroll in private institutions might well envy Congar who pioneered the reverse of that process in New Jersey. Congar, Pennington, and the rest failed in their attempt to reform society by means of the public school. Other forces, acquisitiveness, industrialism, and mobility shaped society often more than the idealism that they tacked to their banners. They had been the agents for these forces, too, although they would not always have approved the way they worked out. Theirs was not the first generation of which this can be said, nor the last. Yet, who would doubt that the school was an anchor to the windward, offering elements of stability and ameliorating the grosser consequences of an acquisitive society?

As for Congar, what manner of man was he once we get behind the public image of the Whig reformer? Certainly, no paranoiac, neither his public nor his private statements ever hint of stridency. As with other New Jersey physicians who threw themselves into school reform, Congar was no promoter; zest for acquisition was not in him. ${ }^{72}$ Nor is it satisfying to put down his efforts to the desire to regain lost status. Stephen Congar was not losing. The son of a carpetweaver become physician, a leader in the social and political life of his city, he walked on equal terms with the others who ruled Newark. However ingenious the theory that reformers defended or sought to restore traditional American values in order to regain a lost sense of power and fulfillment, it does not dislodge the obvious point that those with wealth, status, or both not only had a stake in moral and religious orthodoxy but easily persuaded themselves that they stood for the Right. ${ }^{73}$ Congar reflected the serenity and even noblesse oblige that doubted neither historic American values as he understood them nor his own capacity to live by them whatever specific path he might choose. Early on, he made his bid to lead the medical profession and also assayed his skill in letters. But after throwing in his lot in I 838 with the School Committee, he increas-

${ }^{72}$ Congar was provident; he did not sell his wife's farm when he could not get his price and he worked it successfully. But money-making never dominates his thinking. See for example his letters to Horace, 2 April i 863 , 30 October I 864 .

${ }^{73}$ William W. Cutler III, "Status, Values, and the Education of the Poor: The Trustees of the New York Public School Society, 1805-1853," 24 (American Quarterly) March 1971 , pp. 67-85, pp. 73-79. 
ingly turned his attention to the new world of emerging common schools. Service in the state legislature only seemed to nourish his school interests; and when he left the legislature, in I 854, he was the acknowledged leader of education in Newark.

Yet, four years after he had created the model New Jersey public school system, he could resign his post in the middle of the school year to bring to order the affairs of his newly-won wife. Her property, though substantial, was not so great that he did not have to earn a living, so he turned to operating his wife's farm. "Hirelings" did much of the heavier work, but he had become, and remained to the end of his working life, a "dirt" farmer. As with Joseph P. Kennedy, for him home had no terrors. Not yet fifty when he resigned from the school system, until that time he had passed his whole adult life in professional and public affairs. Then he married and walked away from it with scarcely a backward glance.

Congar, undoubtedly, sought status. No one is entirely immune to the attraction of prestige. Unquestionably, too, he felt a sense of mission. He could fight for legislation for working men but he never identified with them. When he employed them on his farm, they were "hirelings." In the end, he probably did what he did because it caught his interest at the time. Samuel H. Pennington gave up his practice and founded and ran the Newark City Bank because he was interested in making money. Pennington went one way and Congar went another, both, at least in part, seeking power. But there was no lust in Congar, no frenzy, no fever for it. He was the constant amateur trying his hand, never surrendering the whole of himself to public life. His clear, balanced mind never reached the profound. If Scott was not his favorite author, he was certainly among his favorites. ${ }^{74}$ His novel is a bad imitation of the Scott genre (if one can think of Scott in a Fourth of July setting). His school system, the signal achievement of his public life, came from his energy, his intelligence and perception, his careful study rather than from creative imagination. In this, he gave New Jersey its model school system that retained its quality for a full century. Incidentally, he laid the groundwork in the normal school for what eventually was to become Kean College of New Jersey. In a very real sense he is the father of that institution. When he found his system was working, he dropped it, went West, and took up the life of a prosperous

${ }^{74} \mathrm{He}$ was buying Scott works about the time he was writing his novel, see his receipt book, $183_{1}-1854$, in the New Jersey Historical Society. 
farmer, showing, as he wrote his brother, that a city man can learn to run a farm. To the end he remained the gifted amateur.

For suggestions from Edward Pessen and Robert J. Fridlington, the author is very grateful. 